\title{
Trends in Greenhouse Gas Emissions and Renewable Energy Policies in the EU and USA, with Special Emphasis on the Transportation Sector
}

\author{
J. T. KISS' ${ }^{1}$ G. BELLÉR² , I. ÁRPÁD³ ${ }^{3}$ D. KoCSIS² \\ ${ }^{1}$ University of Debrecen, Faculty of Engineering, Department of Engineering Management and Enterprise, \\ tkiss@eng.unideb.hu \\ ${ }^{2}$ University of Debrecen, Faculty of Engineering, Department of Environmental Engineering, \\ beller.gabor@eng.unideb.hu; kocsis.denes@eng.unideb.hu \\ ${ }^{3}$ University of Debrecen, Faculty of Engineering, Department of Mechanical Engineering, \\ arpad.istvan@eng.unideb.hu
}

Abstract. The aim of this work is to review recent trends in the field of greenhouse gas (GHG) emissions and renewable energy policies of the European Union and the United States of America. During the last few decades, there was a significant shift within the political attitude towards these fields, therefore important changes were realized in the electricity production and the climate policy. In the present paper, we discuss the current situation focusing on the transportation segment.

\section{Introduction}

With the Paris Agreement (signed in 2016)[1], the large majority of the world pledged to decrease global warming. Unlike its predecessor, the Kyoto Protocol (signed in 1997)[2], the Paris Agreement allows for voluntary and nationally determined targets, i.e. the climate goals are politically encouraged, rather than legally bound.

Although in 2017, U.S. President Donald Trump announced his intention to withdraw the United States (U.S.) from the Paris Agreement, the EU has committed to carbon neutrality by 2050. To this purpose, the EU has made an energy rulebook called the "Clean energy for all Europeans package"[3], which serves as the EU's long-term strategy of decarbonisation. Each member state must take into account the goals and the countries must determine, plan, and regularly report on the contribution that it undertakes to mitigate the increase in the global average temperature.

By 2030, the targets of the EU's climate policy are to reduce greenhouse gas (GHG) emissions $40 \%$ compared to 1990 levels and to fulfil at least 32\% of its total energy needs with renewables [4].

Drastically cutting GHG emissions requires strong measures not only in the Emissions Trading System (ETS) but also in the sectors of non-ETS, such as waste, agriculture, buildings, transport etc. Within the transport sector, which alone accounts for over $24 \%$ of the anthropogenic GHG emissions worldwide, road vehicles are the largest emitters with a share of $74 \%$. One of the most concerning and challenging 
problems of the near future is the fact that even though global emissions need to be going down, transport emissions are on the rise. In the U.S., emissions of the electric power and industrial sectors decreased compared to 1990, yet, transportation-related emissions elevated, mostly, due to the increased demand for travel.

Alongside the efforts in reducing GHG emissions, EU has adopted one of the most ambitious energy policies in the world in order to cover nearly $1 / 3$ of the total energy needs by using renewable sources (such as wind, solar, hydro, tidal, geothermal). This policy speeds up procedures to receive permits for projects, promotes innovative technologies, supports consumers to produce their own renewable energy, provides long-term certainty for investors, reduces dependence on energy imports and increases energy security.

Under a regulation of the "Clean energy for all Europeans package", EU members are required to draft 10-year (for 2021-2030) National Energy and Climate Plans (NECPs)[3], outlining how they will meet the 2030 targets for renewable energy.

Unlike the EU, in the U.S. there is no unified renewable energy strategy. States may establish a Renewable Portfolio Standard (RPS) which is a regulation that requires the increased production of energy from renewable sources, but RPS policies are not adopted in all states.

\section{The renewable energy and greenhouse gas emissions development over time in the EU}

The measures to decrease greenhouse gas (GHG) emissions, improve energy efficiency and increase the share of renewable energy in the total energy consumption should be encouraged in the interest of sustainable development. Within the framework of the Directive 2008/57/EC of the European Parliament and of the Council of 11 December 2018 on the promotion of the use of energy from renewable sources, it is appropriate to increase the share of renewable energy to $32 \%$ at Union level by 2030 (European Union, 2018). The EU invites the Member States to define their national contributions achieving the target for 2030 and to reach the long-term decarbonisation goals. The EU 28 average for the share of renewable energy in gross final energy consumption was $18 \%$ in 2018, less only by 14 percentage points than the EU-wide target of 32\% in 2030 (Fig. 1). In 2018, the share of renewable energy as a percentage of energy consumption ranged between $7.4 \%$ and $54.6 \%$, and five EU Member States (Austria 33.4\%, Denmark 36.1\%, Latvia 40.3\%, Finland 41.2\% and Sweden 54.6\%) have already reached the $32 \%$ target by 2018 (Fig. 1). Although there was an increase in renewable energy consumption (REC) between 2004 and 2018 that ranged between 4 and 21 percentage points, the share of REC remained at a relatively low level in some countries (Fig. 1). 


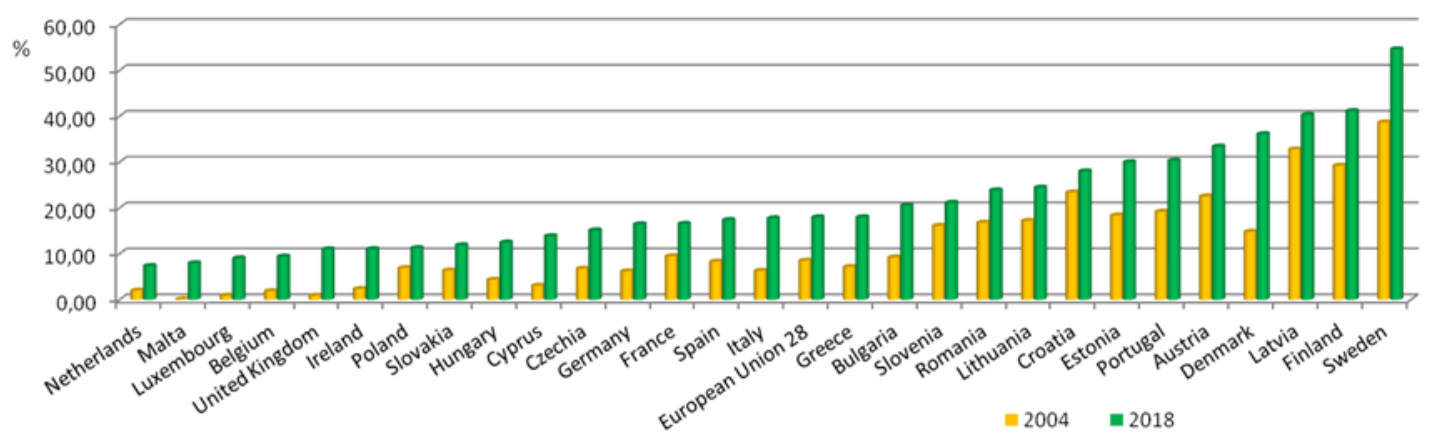

Figure 1. Share of renewable energy in gross final energy consumption in 2004 and 2018 Source: Ref [5]

According to the Hungarian National Energy Strategy, the share of renewable energy in primary energy use requires to raise at least to 21 per cent by 2030. The Hungarian value $(12.5 \%)$ was below the average European Union level in 2018 and 8.5 percentage points below the target value (Fig. 1).

One of the headline targets is to be achieved by 2030, is related to the GHG emissions reduction, namely, the EU based target is to reduce the GHG emissions of $40 \%$ compared to the emissions in 1990.

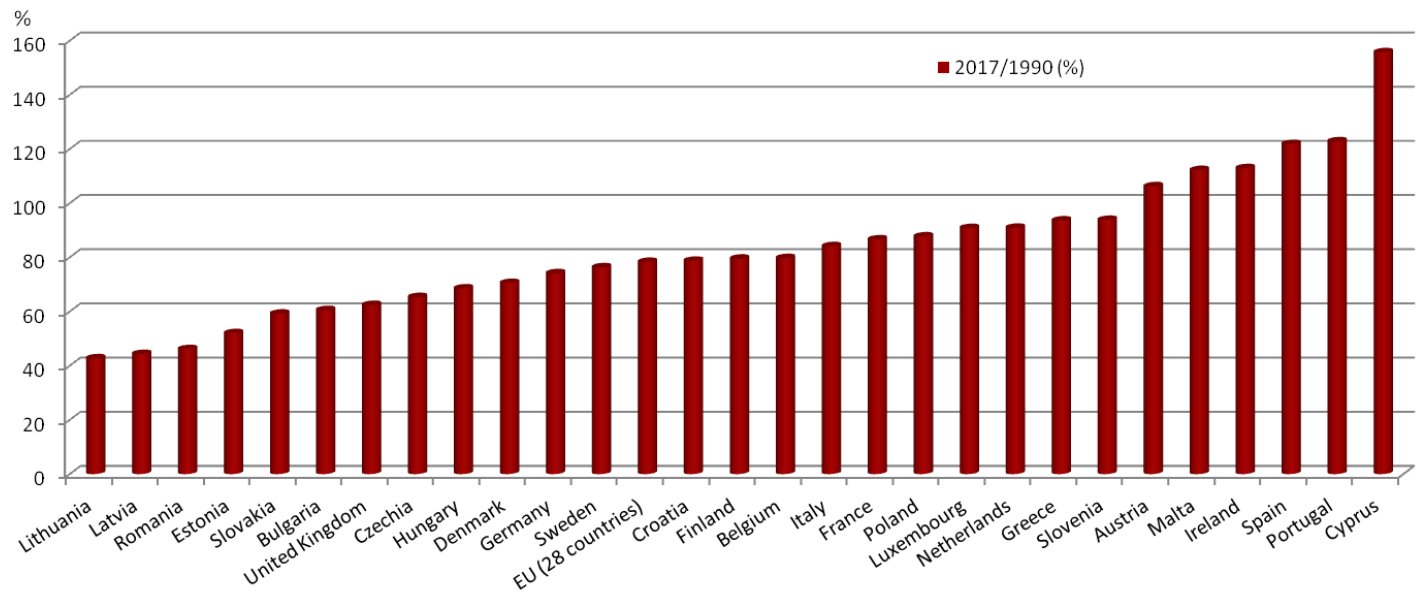

Figure 2. Greenhouse gas emissions (in $\mathrm{CO}_{2}$ equivalent), the base year 1990 Source: $\operatorname{Ref}[6]$

The European Union average in GHG emission was 78.3\% in 2017; however, five countries (Lithuania, Latvia, Romania, Estonia and Slovakia) achieved the target reductions of 40\% in 2017 (Fig. 2). Despite reaching the European Union 2030 target, the reduction in GHG emission has not been to manage in six countries by 2017. The GHG emission of these countries (Austria, Malta, Ireland, Spain, Portugal, and Cyprus) in 2017 compared to 1990 were 106.2\%, 112.2\%, 112.9\%, 121.8\%, 122.8\%, and 155.7\%, respectively (Fig. 2). The greenhouse emissions were the highest in Germany (21.9 thousand tonnes) and the United Kingdom (11.3 thousand tonnes) among the EU Member States in 2017. Only four countries out of $28 \mathrm{EU}$ Member States were responsible for $51.3 \%$ of the EU total GHG emissions (Italy 9.8\%; France 10.8\%; the United Kingdom $11.3 \%$ and Germany $20.9 \%$ ). 
Hungary managed to reduce the GHG emission from 94.2 million tonnes of $\mathrm{CO}_{2}$ equivalents to 64.5 Million tonnes of $\mathrm{CO}_{2}$ equivalents between 1990 and 2017 that represented $1.4 \%$ of the total EU emissions in 2017 [6].

The European Council called attention to the importance of decreasing GHG (greenhouse gas emissions) and risks related to fossil fuel dependency in the transport sector, highlighting the relevance of promotion of emissions reduction and energy efficiency in transport, for electric transportation and renewable energy sources in transport also after 2020 [7].

The share of renewable energy sources in the transport sector in all EU countries increased between 2004 and 2017. The largest share was reported for Sweden (32.1\%) and Finland (18.8\%) well over the European Union average (6\%), and the two mentioned countries achieved the most significant growth in the examined period of 17.8 percentage points and 25.2 percentage points, respectively (Fig. 3 ).

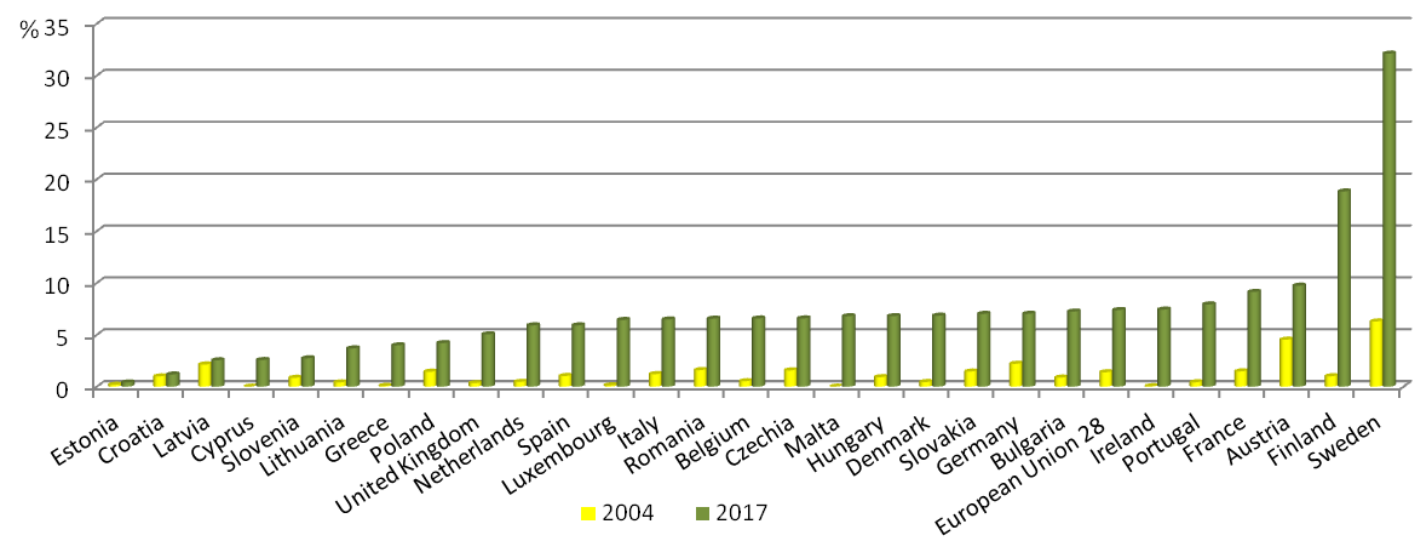

Figure 3. Share of renewable energy in gross final energy consumption - Transport sector in 2004 and 2018 Source: [8]

The transport sector represents the second-highest proportion of total GHG emissions alongside fuel combustion and fugitive emissions from fuels (without transport), the GHG emissions of the two sectors relative to the total emissions were $24.6 \%$, and $54 \%$ respectively in 2017. Although the GHG emissions decreased in most sectors between 1990 and 2017, a substantial increase was observed in the transport sector by 9.6 percentage points [6]. The GHG emissions in the transport sector increased in most EU member states in the examined period, except for five countries (Sweden, Finland, Italy, Lithuania, and Estonia) [9]. The energy sector accounted for the most significant $\mathrm{CO}_{2}$ emission (84.4\%) in all sectors in 2017, while the transport sector represented the second-largest emission with a share of $24 \%$ in the European Union [10]. Although the number of vehicles in the EU increased by $11 \%$ from 2010 to 2018, the average $\mathrm{CO}_{2}$ emissions per kilometre from new passenger cars decreased by at least $10 \%$ in all EU Member States (Fig. 4.). The most significant decrease occurred in Bulgaria, Latvia, Cyprus, Finland, Netherlands and Greece by 20\%, 20.4\%, 20.9\%, 21.8\%, 22.3\% and 22.7\%, respectively [11]. The EU target for the $\mathrm{CO}_{2}$ emissions of new cars already achieved in 2013 and the EU average value was 119.5 grams of $\mathrm{CO}_{2}$ per kilometre in 2015, below the target value. The EU fleet-wide emissions increased to 120.4 grams of $\mathrm{CO}_{2}$ per kilometre in 2018, while two countries' values were above the target value of 2015 . 


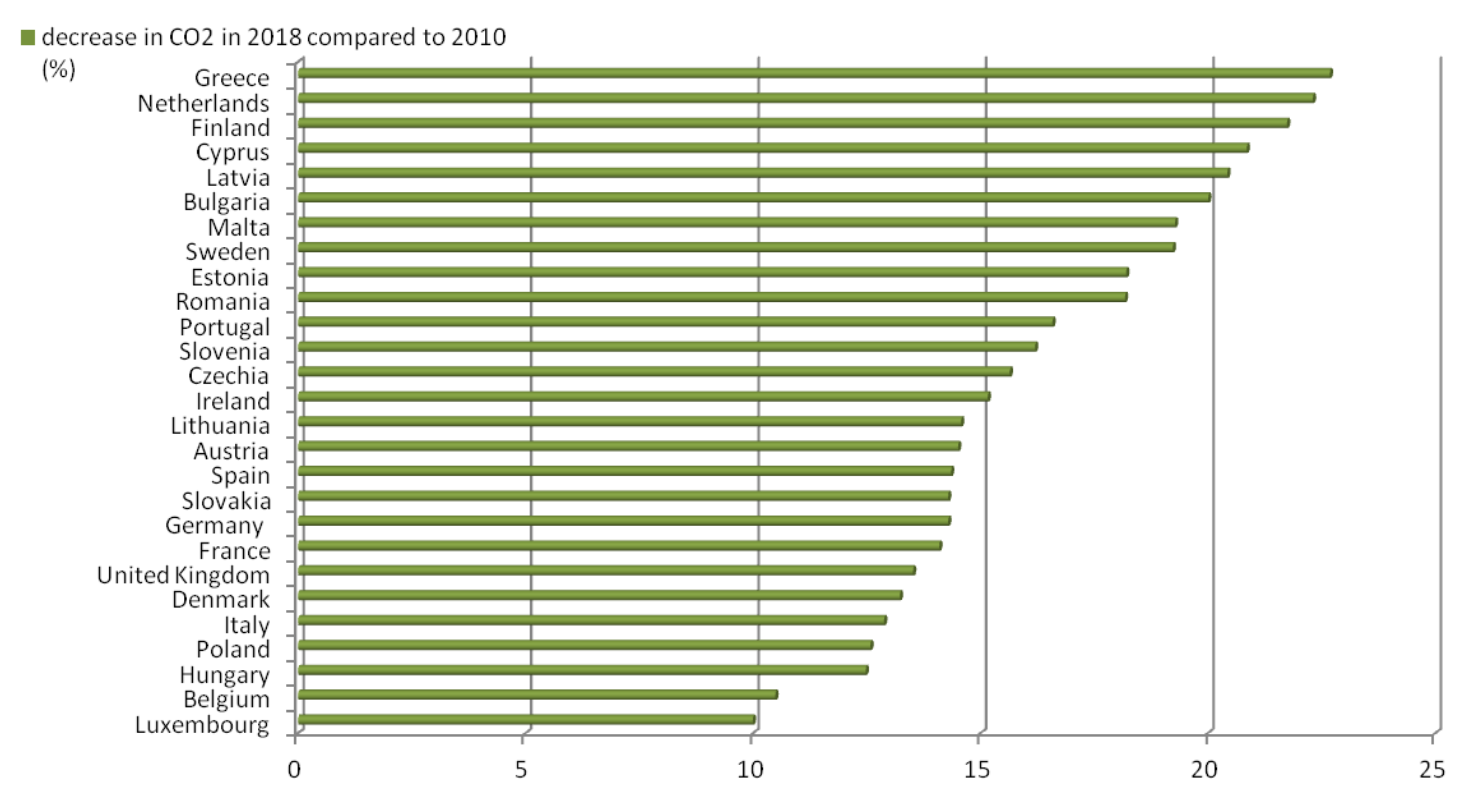

Figure 4. The amount of decrease in average $\mathrm{CO}_{2}$ emissions per $\mathrm{km}$ from new passenger cars in 2018 compared to 2010

Source: $\operatorname{Ref}[11]$

Many investigations were carried out to analyse the life-cycle cost structures of vehicles, and to compare the social and total owner's costs of electric vehicles (battery electric vehicles - BEV, hybrid electric vehicles - HEV) and conventional vehicles (internal combustion engine vehicles - ICEV) [12][17]. Researchers highlighted the need of the government subsidisation to enhance market admission of the electric vehicles since, for example, the battery-electric vehicles acquisition cost and the cost of battery change represents high expenditures for the consumers. Studies established that the electric vehicles perform worse in terms of total life-cycle cost compared the conventional vehicles [12], [13], [15], [17].

Researchers revealed in the examination of the life-cycle emissions of electric vehicles and conventional vehicles that the electric vehicles with coal-based electricity had the life-cycle emissions higher relative to conventional vehicles [12], [18]. Wolfram \& Wiedmann (2017) [19] identified that if electricity production relied on coal power, the electric vehicles had a higher carbon footprint compared to conventional vehicles, while the hybrid electric vehicles have the lowest carbon footprint. Although the environmental impacts of electric vehicles strongly depend on the features of the vehicles (vehicle and battery lifetime, energy used) and electricity production [18], [20], the European Environment Agency [21] pointed out that countries that foster the market penetration of zero- and low-emitting cars such as electric vehicles (battery electric vehicles (BEVs) and plug-in hybrid vehicles (PHEVs)), can reduce the $\mathrm{CO}_{2}$ emissions significantly. The positive change of the prementioned indicator for the average $\mathrm{CO}_{2}$ emissions from new passenger cars was partly attributable to the increase in the number of alternative fuel cars. The number of new electric vehicles increased from 734 to 294352 between 2010 and 2018, and this means that the ratio of new electric vehicles to the total number of vehicles exceeds $2 \%$ in 2018 (Table 1 ). 


\begin{tabular}{|l|c|c|c|c|}
\hline & Battery electric & Electric plug-in & Total vehicles & Share of electric vehicles (\%) \\
\hline $\mathbf{2 0 1 0}$ & 734 & & 13181154 & 0,006 \\
\hline $\mathbf{2 0 1 1}$ & 7759 & & 12829535 & 0,060 \\
\hline $\mathbf{2 0 1 2}$ & 13986 & 9000 & 12031054 & 0,191 \\
\hline $\mathbf{2 0 1 3}$ & 24175 & 31167 & 11868737 & 0,466 \\
\hline $\mathbf{2 0 1 4}$ & 37855 & 68180 & 12541978 & 0,845 \\
\hline $\mathbf{2 0 1 5}$ & 64316 & 103553 & 13770826 & 1,219 \\
\hline $\mathbf{2 0 1 6}$ & 56756 & 93707 & 14714327 & 1,023 \\
\hline $\mathbf{2 0 1 7}$ & 97143 & 126898 & 15129296 & 1,481 \\
\hline $\mathbf{2 0 1 8}$ & 148454 & 145898 & 14701753 & 2,002 \\
\hline
\end{tabular}

Table 1. Number of new electric vehicles in the EU-28 between 2010 and 2018

Source: Ref [22]

\section{Recent trends in United States GHG emissions and renewable energy policy}

In 2017, total gross of GHG emissions in the U.S. was 6456.7 million tonnes (MT) $\mathrm{CO}_{2}$ equivalent (excluding emissions and removals from Land Use, Land Use Change, and Forestry, LULUCF),[23] as a comparison, the EU emission in the same year was 4483.1 $\mathrm{MT} \mathrm{CO}_{2}$ eq.[10] Between 1990 and 2017, total US emissions peaked in 2005 (Fig. 5.). Although comparing the 2017 data with 1990, the total emissions have increased by 1.3 percent, since 2005, a steady decrease occurred until 2017 (-12\%, $882 \mathrm{MT} \mathrm{CO}_{2}$ eq.) [23]. In recent years, the decrease in total GHG emissions was driven in part by a decrease in emissions from fossil fuel combustion. This is the result of multiple factors, including a continued shift from coal to natural gas and increased use of renewable energy in the electric power sector. Electricity generation from renewable sources increased by 35.9 percent from 2013 to 2017 and natural gas generation increased by 16.3 percent over the same time period.

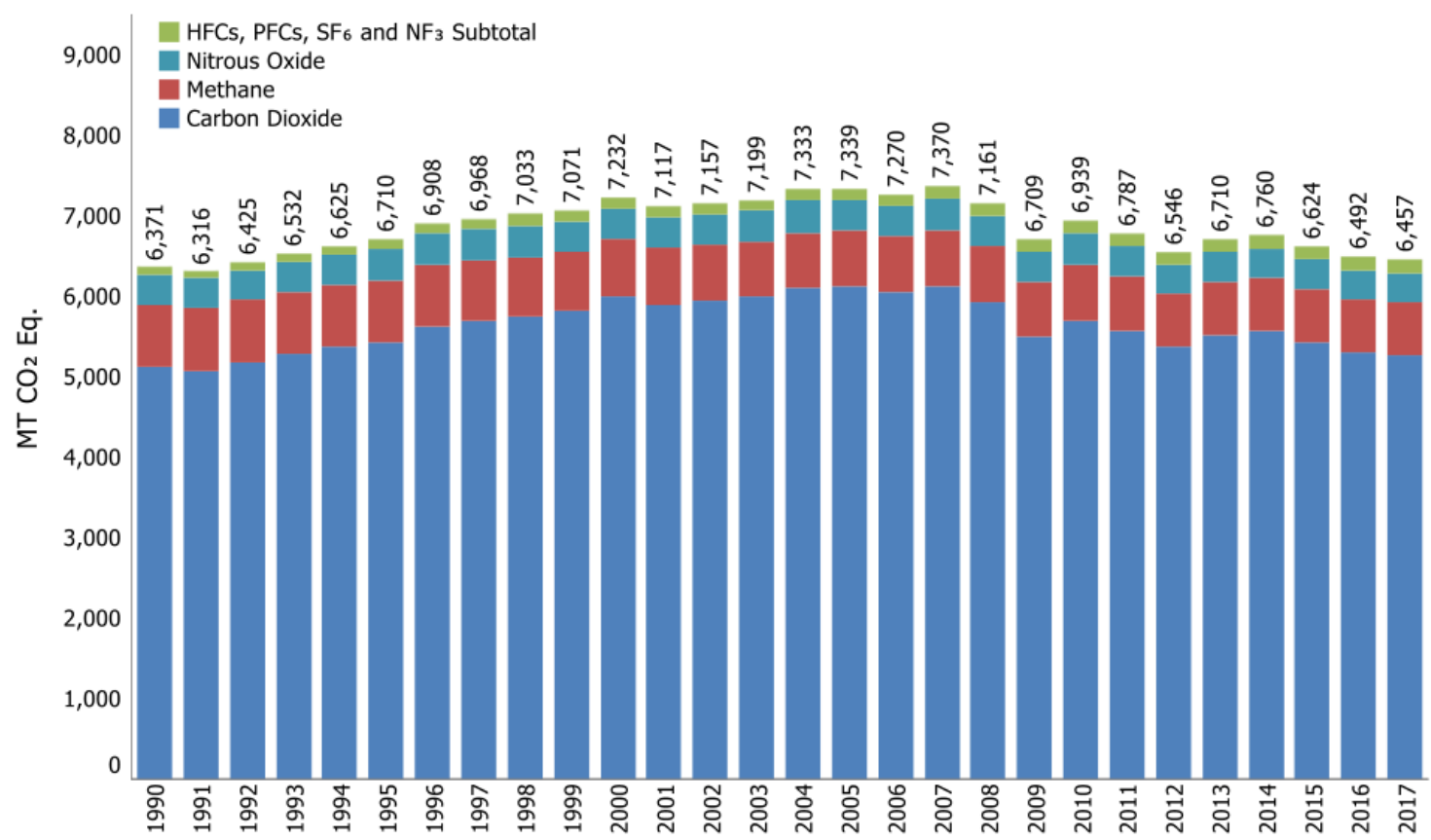

Figure 5 Gross U.S. Greenhouse Gas Emissions by Gas

Source: Ref [23] 
During the entire time series since 1990, the largest part of $\mathrm{CO}_{2}$ (the most important GHG) emission is due to the combustion of fossil fuels. In 2017, fossil fuel combustion has accounted for $93.2 \%$ of the $\mathrm{CO}_{2}$ emission, and within this segment, transportation (36.7\%), electric power sector $(35.3 \%)$ and other industrial combustion processes (16.5\%) are the most significant sources [23]. The electric power sector and industrial emissions decreased by 4.8 and 5.5 percentage points compared to 1990, respectively. However, transportation-related emissions increased by $22.5 \%$ due, in large part, to increased demand for travel and the fact that almost all of the energy used for transportation was supplied by petroleum-based products. In 2017, the sources of nearly $60 \%$ of the transportationrelated GHG emissions were the light-duty vehicles, including passenger cars (41.2\%) and light-duty trucks (17.5\%), e.i. sport utility vehicles (SUVs), pickup trucks, and minivans. The remaining emission of this sector came from other modes of transportation, such as freight trucks $(23.3 \%)$, commercial aircraft (6.9\%), ships and boats (2.4\%), and trains (2.2\%).

The US National Program for GHG emissions and fuel economy standards for light-duty vehicles was developed jointly by the Environmental Protection Agency (EPA) and the National Highway Traffic Safety Administration (NHTSA). The standards were established in two phases: model years 2012 2016 as Phase 1 [24]; and model years 2017 - 2025 as Phase 2 [25]. The U.S. standards for Phase 2 are listed in Table 2, which are clearly less severe than the corresponding EU targets [7]. In September 2019, EPA and NHTSA issued a final action entitled the "One National Program Rule" to enable the federal government to provide nationwide uniform standards [26]. This action finalizes critical parts of the Safer, Affordable, Fuel-Efficient (SAFE) Vehicles Rule that was first proposed in August 2018 [27]. The technologies available for automakers to meet the Phase 2 standards include advanced internal combustion engines and transmissions, vehicle weight reduction, lower tire rolling resistance, improvements in aerodynamics, more efficient accessories, and improvements in air conditioning systems. Some increased electrification of the fleet is also expected through the expanded use of stop/start systems, HEVs, PHEVs, and BEVs.

\begin{tabular}{|l|c|c|c|c|c|c|c|c|c|c|}
\hline & 2016 & 2017 & 2018 & 2019 & 2020 & 2021 & 2022 & 2023 & 2024 & 2025 \\
\hline $\begin{array}{l}\text { GHG standard } \\
\text { (g/mile) }\end{array}$ & 250 & 243 & 232 & 222 & 213 & 199 & 190 & 180 & 171 & 163 \\
\hline $\begin{array}{l}\text { GHG standard } \\
\text { (g/km) }\end{array}$ & 155 & 151 & 144 & 138 & 132 & 124 & 118 & 112 & 106 & 101 \\
\hline
\end{tabular}

Table 2. Combined Average Passenger Car and Light Truck GHG Emission Standards for Model Years 2017-2025

Source: $\operatorname{Ref}[25]$

The energy policy of the United States is determined by federal, state, and local entities in the U.S., which address issues of energy production, distribution, and consumption. A Renewable Portfolio Standard (RPS) is a regulation that requires the increased production of energy from renewable energy sources, such as wind, solar, biomass, and geothermal. There is no unified RPS program in the U.S.: only 29 of 50 states established RPS mechanism, further 8 states set voluntary renewable energy goals, while 13 states have no declared targets (Fig. 6). 

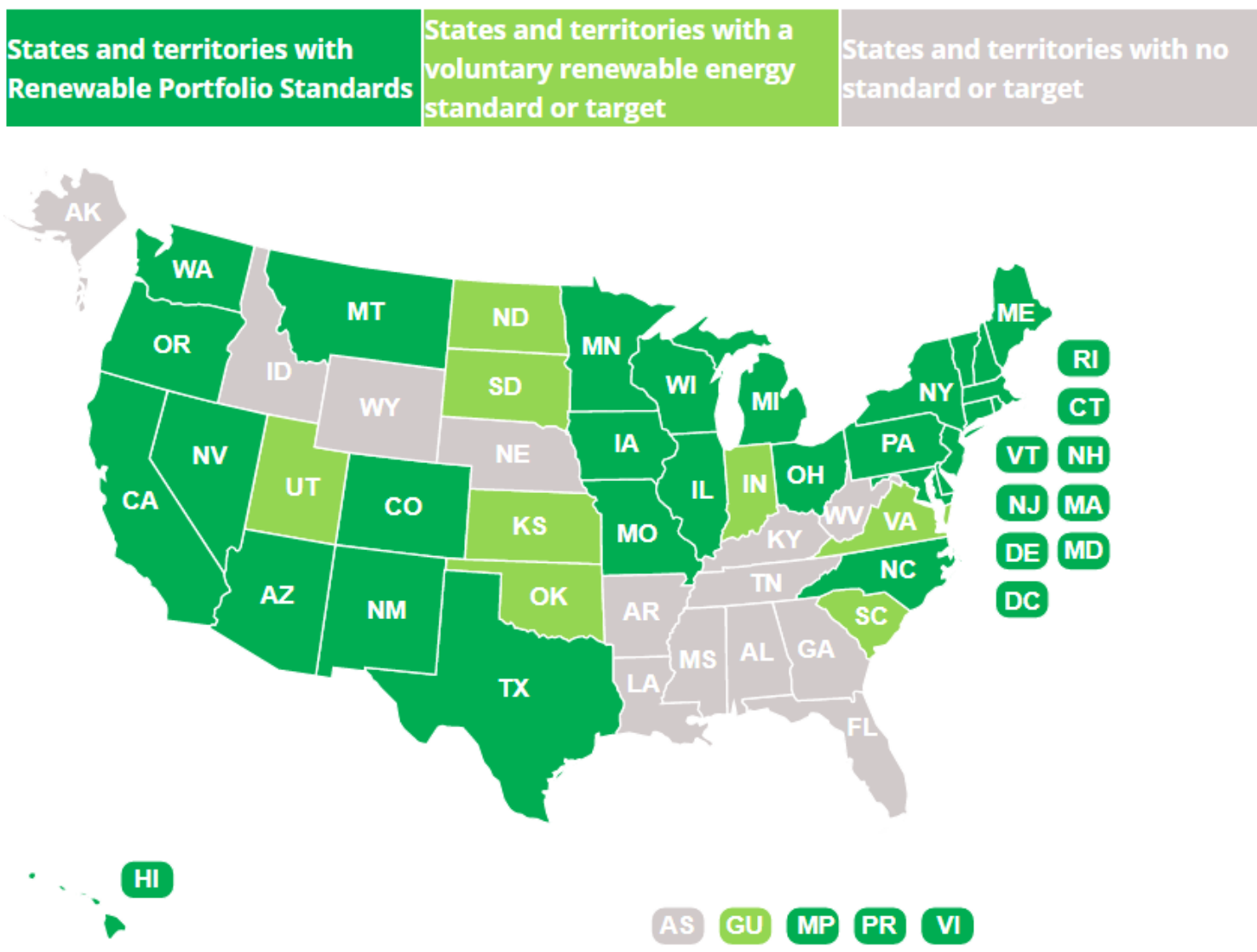

Figure 6 Renewable Energy Policy of U.S. States.

Source: Ref [28]

State RPS policies vary widely on several elements including targets, the entities they include, the resources eligible to meet requirements and cost caps. In many states, standards are measured by the percentage of retail electric sales. While most state targets are between $10 \%$ and $45 \%$, 13 states California, Colorado, Hawaii, Maine, Maryland, Massachusetts, Nevada, New Mexico, New Jersey, New York, Oregon, Vermont, Washington - have requirements of $50 \%$ or greater.

Due to the RPS policies, the annual total renewable energy production nearly doubled between 2000 and 2018 [29]. In the latest long-term projections, the U.S Energy Information Administration (EIA) projects electricity generation from renewable sources such as wind and solar to surpass nuclear and coal by 2021 to exceed natural gas in 2045 [30].

\section{3. $\mathrm{CO}_{2}$ vehicle emission measuring procedures in the EU}

The EU determined $\mathrm{CO}_{2}$ emissions reduction targets (introduced in Regulation (EC) 2009/443 [31]) for new cars of 130 grams of $\mathrm{CO}_{2}$ per kilometre until the end of 2019. From 2020 onwards, the Regulation (EC) 2019/631 determines the specific emission targets. For the calendar year 2020, the specific emissions of $\mathrm{CO}_{2}$ for each new passenger car is 95 grams of $\mathrm{CO}_{2}$ per kilometre, it must be met by $95 \%$ of each car manufacturers' newly registered cars. From 2021 100\% of the certified vehicles shall be involved in the calculation. 
The specific $\mathrm{CO}_{2}$ target values that car companies must meet by 2021 are based on the New European Driving Cycle (NEDC) test procedure. In September 2017 new European test came into force called the World Harmonised Light Vehicles Test Procedure (WLTP) replacing the old NEDC. The NEDC was designed in the 1980s, and it was lastly updated in 1995. As a result of technological advancements and changes in driving conditions, it became obsolete. It used a theoretical driving profile, which was overwritten by the WLTP's real-driving data gathered from around the world. Due to the complexity of WLTP the adaptation was phased in. All new passenger car models (PCs) are tested according to WLTP since September 2017. For the registration of all new PCs the WLTP is mandatory since September 2018. It is also required for Light Commercial Vehicles (LCVs) since September 2019. Further requirements are also obligatory since September 2019 including measurements of emissions deriving from evaporation [32]. During 2020 the EC will convert NEDC-based $\mathrm{CO}_{2}$ targets to specific WLTP-CO targets of comparable stringency.

The aim of the WLTP is to measure fuel consumption, $\mathrm{CO}_{2}$ emissions, pollutant emissions and energy consumption values of alternative powertrains (as well as the range of electric vehicles) in a more accurate way. Therefore, the test procedure is much longer, more dynamic and focuses on more realworld parameters than the previous NEDC test (Table 3).

\begin{tabular}{|c|c|c|}
\hline & $N E D C$ & WLTP \\
\hline Test cycle & Single test cycle & $\begin{array}{c}\text { Dynamic cycle more representative of real } \\
\text { driving }\end{array}$ \\
\hline Cycle time [min] & 20 & 30 \\
\hline Cycle distance [km] & 11 & 23.25 \\
\hline Driving phases & $\begin{array}{c}2 \text { phases: } 66 \% \text { urban and } 34 \% \text { non-urban } \\
\text { driving }\end{array}$ & $\begin{array}{l}4 \text { more dynamic phases: } 52 \% \text { urban and } \\
48 \% \text { non-urban driving }\end{array}$ \\
\hline Average speeds [km/h] & 34 & 46.5 \\
\hline $\begin{array}{c}\text { Maximum speed } \\
{[\mathrm{km} / \mathrm{h}]}\end{array}$ & 120 & 131 \\
\hline $\begin{array}{c}\text { Influence of optional } \\
\text { equipment }\end{array}$ & $\begin{array}{c}\text { Impact on } \mathrm{CO}_{2} \text { and fuel performance not } \\
\text { considered under } \mathrm{NEDC}\end{array}$ & $\begin{array}{c}\text { additional feature (which can differ per } \\
\text { car) are taken into account }\end{array}$ \\
\hline Gear shifts & Vehicles have fixed gear shift points & Different gear shift points for each vehicle \\
\hline Test temperatures & Measurements at $20-30^{\circ} \mathrm{C}$ & $\begin{array}{c}\text { Measurements at } 23^{\circ} \mathrm{C}, \mathrm{CO}_{2} \text { values } \\
\text { corrected to } 14^{\circ} \mathrm{C}\end{array}$ \\
\hline
\end{tabular}

Table 3. The most important differences between NEDC and WLTP tests

Source: Ref [32]

The WLTP test is a significant improvement over NEDC, as it much longer and the procedure involves much faster accelerations, but it is still not appropriate for simulating real-world conditions. It eliminates many former practices that car manufacturers used to artificially lower NEDC emission results, like over-inflating tyres, and charging the battery before the test [33]. It also pays attention to 
the car' weight, as testing in minimum and maximum weight is required. Therefore, WLTP tests are generally much more representative than the former ones [34]-[37], but there is still a significant gap between real-world emissions and the WLTP laboratory results. Based on measured data it can be estimated that the approximately 15-31\% additional increase can be observed in real-world situation compared to the WLTP test [38], [39]. This gap is expected to grow in the near future mostly due to adaptation to the procedure flexibilities [32].

\section{Conclusion}

According to the EU 2020 strategy and the Renewable Energy Directive adopted in 2018, the renewable energy share should reach at least $20 \%$ by 2020 and $32 \%$ by 2030 . The EU average of the share of renewable energy in gross final energy consumption was $18 \%$ in 2018, less only by two percentage points than the target of $20 \%$ in 2020 . In 2018, the share of renewable energy as a percentage of energy consumption already achieved the target for 2030 in five EU members. The EU average greenhouse gas emissions in the EU decreased by 21.7 percent in 2017 compared to the 1990 level, thus going beyond the Europe 2020 goal of reducing the GHG emissions by 20 percent by 2020 . Moreover, five European countries already met the target for 2030 (the reduction of GHG emissions by $40 \%$ of the level in 1990). However, the emissions in the transport sector increased in most EU member states between 1990 and 2017 with the exceptions of five countries.

Despite the diverse energy policies of the U.S. states, the total renewable energy production increased by $90 \%$ between 1990 and 2018 and in the ranking of energy sources, renewable is predicted to surpass coal and become 2 nd only to natural gas within few years.

Climate policy in the U.S. has transformed rapidly over the past decades depending on the leading political party and is being developed at both state and federal level. Partly because of the changing policy, the gross GHG emissions hardly have shifted since 1990, in contrast to the impressive decrease in the EU. By far the largest source of $\mathrm{CO}_{2}$ is the combustion of fossil fuels. Among the fossil fuel using sectors, electric power and industrial divisions cut the emissions to a small extent (4.8 and 5.5\%, respectively), but transportation-related emissions increased by $22.5 \%$ between 1990 and 2017 .

In terms of $\mathrm{CO}_{2}$ emission measurements, the new WLTP procedure is a significant development towards more realistic measurements, compared to the outdated NEDC. Despite the progress, a gap still exists between the laboratory test and the real-world emissions. Altogether, meeting the new requirements will be a major challenge for the members of the sector.

\section{Acknowledgement}

The research was financed by the Thematic Excellence Programme of the Ministry for Innovation and Technology in Hungary (ED_18-1-2019-0028), within the framework of the (Automotive Industry) thematic programme of the University of Debrecen. 


\section{References}

[1] UNFCCC. Conference of the Parties (COP), "Paris Climate Change Conference-November 2015, COP 21," 2015.

[2] UNFCCC, "Kyoto Protocol to the United Nations Framework Convention on Climate Change adopted at COP3," Kyoto, Japan , 1997.

[3] EC, “Clean Energy For All Europeans Communication,” 2016.

[4] European Union., "Directive (EU) 2018/2001 of the European Parliament and of the Council on the promotion of the use of energy from renewable sources," Off. J. Eur. Union, vol. 2018, no. November, pp. 1-128, 2018.

[5] Eurostat, "Share of renewable energy in gross final energy consumption." [Online]. Available: https://ec.europa.eu/eurostat/databrowser/view/T2020_31/default/table. [Accessed: 31-Jan2020].

[6] Eurostat, “Greenhouse gas emission statistics-emission inventories.”

[7] European Commission, "REGULATION (EU) 2019/631 OF THE EUROPEAN PARLIAMENT AND OF THE COUNCIL of 17 April 2019 setting CO2 emission performance standards for new passenger cars and for new light commercial vehicles, and repealing Regulations (EC) No 443/2009 and (EU) No 510/201," Off. J. Eur. Union, vol. 25.4.2019, no. L 111/13, 2019.

[8] Eurostat, "Share of renewable energy in gross final energy consumption by sector." [Online]. Available:

https://ec.europa.eu/eurostat/databrowser/view/sdg_07_40/default/table?lang=en. [Accessed: 31-Jan-2020].

[9] EEA, "Data viewer on greenhouse gas emissions and removals, sent by countries to UNFCCC and the EU Greenhouse Gas Monitoring Mechanism (EU Member States)." [Online]. Available: https://www.eea.europa.eu/data-and-maps/data/data-viewers/greenhouse-gases-viewer. [Accessed: 20-Jan-2020].

[10] European Environment Agency, "Data viewer on greenhouse gas emissions and removals, sent by countries to UNFCCC and the EU Greenhouse Gas Monitoring Mechanism (EU Member States)." .

[11] Eurostat, "Average CO2 emissions per km from new passenger cars.” [Online]. Available: https://ec.europa.eu/eurostat/databrowser/view/sdg_12_30/default/table?lang=en. [Accessed: 31-Jan-2020].

[12] L. A. W. Ellingsen, "The size and range effect: Life-cycle greenhouse gas emissions of electric vehicles," CONCAWE Rev., vol. 2017, p. 6, 2017.

[13] S. Kara, W. Li, and N. Sadjiva, "Life Cycle Cost Analysis of Electrical Vehicles in Australia," Procedia CIRP, vol. 61, pp. 767-772, 2017.

[14] L. K. Mitropoulos, P. D. Prevedouros, and P. Kopelias, "Total cost of ownership and externalities of conventional, hybrid and electric vehicle," Transp. Res. Procedia, vol. 24, no. 2004, pp. 267274, 2017.

[15] M. Potkány, M. Hlatká, M. Debnár, and J. Hanzl, "Comparison of the lifecycle cost structure of electric and diesel buses," Nase More, vol. 65, no. 4 Special issue, pp. 270-275, Oct. 2018.

[16] P. Prevedouros and L. Mitropoulos, "Life Cycle Emissions and Cost Study of Light Duty Vehicles," Transp. Res. Procedia, vol. 15, pp. 749-760, 2016.

[17] A. Rusich and R. Danielis, "Total cost of ownership, social lifecycle cost and energy consumption 
of various automotive technologies in Italy," Res. Transp. Econ., vol. 50, pp. 3-16, 2015.

[18] T. R. Hawkins, B. Singh, G. Majeau-Bettez, and A. H. Strømman, "Comparative Environmental Life Cycle Assessment of Conventional and Electric Vehicles," J. Ind. Ecol., vol. 17, no. 1, pp. 53-64, 2013.

[19] P. Wolfram and T. Wiedmann, "Electrifying Australian transport: Hybrid life cycle analysis of a transition to electric light-duty vehicles and renewable electricity," Appl. Energy, vol. 206, no. August, pp. 531-540, 2017.

[20] A. Elgowainy et al., "Cost of ownership and well-to-wheels carbon emissions/oil use of alternative fuels and advanced light-duty vehicle technologies," Energy Sustain. Dev., vol. 17, no. 6, pp. 626-641, 2013.

[21] European Environment Agency, "Fiscal instruments favouring electric over conventional cars are greener - European Environment Agency." [Online]. Available:

https://www.eea.europa.eu/publications/fiscal-instruments-favouring-electric-over. [Accessed: 31-Jan-2020].

[22] European Environment Agency, "New electric vehicles in the EU-28 - European Environment Agency." [Online]. Available: https://www.eea.europa.eu/data-and-maps/daviz/new-electricvehicles-in-eu-28\#tab-chart_2. [Accessed: 31-Jan-2020].

[23] U.S. Environmental Protection Agency, "Inventory of U.S. greenhouse gas emissions and sinks: 1990-2017,” vol. 84, no. 29. Federal Register, p. 675, 2019.

[24] U. S. Environmental Protection Agency and National Highway Traffic Safety Administration, "Light-Duty Vehicle Greenhouse Gas Emission Standards and Corporate Average Fuel Economy Standards; Final Rule," Fed. Regist., vol. 75, no. 88, 2010.

[25] U. S. Environmental Protection Agency and National Highway Traffic Safety Administration, "Final Rule for Model Year 2017 and Later Light-Duty Vehicle Greenhouse Gas Emissions and Corporate Average Fuel Economy Standards," Fed. Regist., vol. 77, no. 199, 2012.

[26] U. S. Environmental Protection Agency and National Highway Traffic Safety Administration, "The Safer Affordable Fuel-Efficient (SAFE) Vehicles Rule Part One: One National Program," Fed. Regist., vol. 84, no. 188, 2019.

[27] U. S. Environmental Protection Agency and National Highway Traffic Safety Administration, "The Safer Affordable Fuel-Efficient (SAFE) Vehicles Rule for Model Years 2021-2026 Passenger Cars and Light Trucks," Fed. Regist., vol. 83, no. 165, 2018.

[28] "State Renewable Portfolio Standards and Goals." [Online]. Available: https://www.ncsl.org/research/energy/renewable-portfolio-standards.aspx. [Accessed: 30Jan-2020].

[29] U.S. Energy Information Administration, "Total Renewable Energy Production, Annual Energy Review." [Online]. Available: https://www.eia.gov/totalenergy/data/annual/index.php. [Accessed: 30-Jan-2020].

[30] U.S. Energy Information Administration, “Annual Energy Outlook 2020,” 2020.

[31] European Comission, "REGULATION (EC) No 443/2009 - setting emission performance standards for new passenger," Off. J. Eur. Communities, 2009.

[32] ECG The Association of European Vehicle Logistics, "WLTP, RDE and automotive emissions targets," 2019.

[33] Transport \& Environment, "CO2 emissions from cars: the facts," Brussels, 2018.

[34] G. Fontaras et al., "The difference between reported and real-world CO2 emissions: How much 
improvement can be expected by WLTP introduction?," Transp. Res. Procedia, vol. 25, pp. 39333943, Jan. 2017.

[35] J. Pavlovic, B. Ciuffo, G. Fontaras, V. Valverde, and A. Marotta, "How much difference in typeapproval $\mathrm{CO} 2$ emissions from passenger cars in Europe can be expected from changing to the new test procedure (NEDC vs. WLTP)?," Transp. Res. Part A Policy Pract., 2018.

[36] A. Dimaratos, D. Tsokolis, G. Fontaras, S. Tsiakmakis, B. Ciuffo, and Z. Samaras, "Comparative Evaluation of the Effect of Various Technologies on Light-duty Vehicle CO2 Emissions over NEDC and WLTP," Transp. Res. Procedia, vol. 14, pp. 3169-3178, Jan. 2016.

[37] J. Pavlovic, A. Marotta, and B. Ciuffo, "CO2 emissions and energy demands of vehicles tested under the NEDC and the new WLTP type approval test procedures," Appl. Energy, vol. 177, pp. 661-670, Sep. 2016.

[38] S. Kumar Pathak, V. Sood, Y. Singh, and S. A. Channiwala, "Real world vehicle emissions: Their correlation with driving parameters," Transp. Res. Part D Transp. Environ., 2016.

[39] S. Tsiakmakis et al., "From lab-to-road \&amp; vice-versa: Using a simulation-based approach for predicting real-world CO2 emissions," Energy, vol. 169, pp. 1153-1165, Feb. 2019. 